\title{
INFLUENCE OF GRAPE GENOTYPE, RIPENING SEASON, SEED TRACE SIZE, AND CULTURE DATE ON IN OVULE EMBRYO DEVELOPMENT AND PLANT FORMATION $\left(^{1}\right.$ )
}

\author{
CELSO V. POMMER $\left({ }^{2}\right)$, DAVID W. RAMMING $\left({ }^{3}\right)$ AND RICHARD L. EMERSHAD $\left({ }^{3}\right)$
}

\begin{abstract}
Eighteen seedless grape genotypes differing in ripening season (early, mid and late) and in seed trace size (small, medium and largc) were harvested at 6, 10, 14, 18 and 22 weeks past bloom (wpb). Using embryo rescue techniques it was studied if embryo do abort as the fruit matures and what percent embryos remain viable at later stages. The size of seed trace was also investigated to determine its influence on embryo viability during maturation. It was found that genotype have great influence on embryo culture traits. Late maturing genotypes showed fewer rescued embryos, germinated embryos and transplantable plants than early and mid season ones. The best culture time for grape embryo rescue is 6 and 10 wpb. At these dates, the largest number of embryos, germinated embryos and transplantable plants were obtained. Genotypes with the largest ratio for seed trace weight/seed trace length (i.e., largest density) showed the greatest tendency to have the largest number of ovules with embryos, more germinated embryos and more transplantable plants. The study also showed that it is possible to recover plants from mature fruit harvested late, although at a much reduced rate.
\end{abstract}

Index terms: seedless grapes, embryo rescue, genotypes, "in vitro" culture.

( $\left.{ }^{1}\right)$ Research carried out at the Horticultural Crops Research Laboratory, Agricultural Research Service of the United States Department of Agriculture (HCRL/ARS/USDA). Received for publication in October $31^{\text {st }}, 1994$ and approved in June $19,1995$.

$\left({ }^{2}\right)$ Visiting Scientist, Instituto Agrọnômico (IAC), Caixa Postal 28, 13001-970 Campinas, SP, Brasil, with research grant from CNPq.

$\left({ }^{3}\right)$ HCRL/ARS/USDA, 2021 S. Peach Ave. Fresno, CA 93727, USA. 


\title{
RESUMO
}

\section{INFLUÊNCIA DO GENÓTIPO, ÉPOCA DE MATURAÇÃO, TAMANHO \\ DA SEMENTE-TRAÇO E ÉPOCA DA CULTURA SOBRE O DESENVOLVIMENTO DO EMBRIÃO NO ÓVULO E A FORMAÇÃO DA PLANTA DE VIDEIRA}

\begin{abstract}
Dezoito genótipos de uvas (Vitis vinifera L.) apirenas, sem sementes diferindo na época de maturação (precoce, média e tardia) c no tamanho da semente-traço (pequena, média e grande), foram colhidos a $6,10,14,18$ e 22 semanas após o florescimento. Usando técnicas de resgate de embrião, foi estudado se o embrião aborta à medida que o fruto amadurece e quais percentagens de embriões permanecem viáveis em estádios mais avançados. O tamanho da semente-traço também foi investigado para determinar sua influência na viabilidade do embrião durante a maturação. Verificou-se que o genótipo tem grande influência nas características relacionadas com a cultura de embrião. Genótipos de maturação tardia mostraram menos embriōes resgatados e germinados e menos plântulas transplantáveis do que aqueles precoces e médios. As melhores épocas para cultura visando ao resgate de embriăo de uva são as de 6 e 10 semanas após o florescimento. Nessas datas, obtiveram-se os maiores números de embriōes germinados e de plântulas transplantáveis. Genótipos com as maiores relaçōes entre peso de semente-traço/comprimento de semente-traço (isto é, maior densidade) revelaram-se propensos a ter maior número de óvulos com embriōes, mais embriões germinados e mais plântulas transplantáveis. O estudo também mostrou que é possível obter plantas de frutos maduros colhidos tardiamente, embora a uma taxa mais reduzida.
\end{abstract}

Termos de indexação: videira, Vitis vinifera L., resgate de embrião, cultura "in vitro", apirenia.

\section{INTRODUCTION}

The use of seedless grapes in breeding programs has been the basis for the development of seedless grape varieties for the fresh market, replacing sceded varicties because of consumer preference. All the current seedless cultivars, resulting from breeding programs, have originated from seeded females hybridized with seedless males. As shown by Barlass et al. (1988), Ramming (1990) and this is a very inefficient method for the production of seedless populations and for combining genes from seedless genotypes. For example, two generations are needed to combine traits from two seedless genotypes and desired genotypes are diluted with genes from the seeded females.

Until the advent of tissue culture, no method was available to grow plants from seedless grapes even though embryos were shown to exist in aborted seeds of mature fruit of stenospermic grapes (Stout, 1936). The development of embryo rescue tech- niques was first reported by Cain et al. (1983), for stenospermic grapes with large aborted seeds and by Emershad and Ramming $(1982,1984)$ and Emershad et al. (1989) for 'Thompson Seedless' with very small aborted seeds. This has opened an entirely new aspect for breeding seedless grapes and has been used in grape breeding programs ( $\mathrm{Bar}$ lass et al., 1988, Bouquet \& Davis, 1989, and Ramming, 1990). With the direct hybridization of seedless $\mathrm{x}$ seedless genotypes, only one generation is needed. It also results in a higher $\%$ of seedless progeny $(44-85 \%)$, compared to seeded $x$ seedless progeny (14-44\%) (Ramming, 1990).

Surveys of grape varieties to determine the size of the aborted seed and production of embryos and plants through embryo rescue have been made by Goldy and Amborn (1987) and Ramming (1990). In some cases correlations were found. In embryo culture procedures tested and used by various researchers, ovules were taken as early as 10 days and as late as 100 days after bloom, with 40 to 
60 days being the optimum (Cain et al., 1983, Spiegel-Roy et al., 1985, Emershad et al., 1989 and Gray et al., 1990). Bouquet and Davis (1989) found that as the fruit matured, the percent of ovules that developed embryos increased. They harvested fruit July 20, August 3, and August 17 (days after bloom not recorded) and obtained 13.3, 21.9, 39.9\% ovules that developed embryos during culture, respectivcly. Irrespective of the harvest date, the percent of embryos that developed into plants was similar (43.4-45.0\%). There was a significant variety (genotype) effect on percent of embryos recovered after culture. Researchers have not cultured ovules from mature fruit because of the assumption that since the seed had aborted, the embryo was also aborted. Stout (1936) found ovules from Thompson Seedless, Sultanina Rose and other numbered stenospermic selcctions, that contained globular embryos at maturity. He states "cells of such undeveloped embryos often contain nuclei and the cell contents appear to be normal and living even when the berry is fully ripe". Ross (Pearson, 1932) reported germinating 4 aborted seeds from Black Monukka, showing embryos in stenospermic grapes can be viable. In previous experiments (Zhang \& Ramming, unpublished) it was shown that plants could be produced from ovules taken from mature and over-ripe fruit.

This experiment was designed to determine if embryos do abort as the fruit matures and what percent embryos remain viable at later stages of fruit maturity. This could extend the period for cul- turing embryos. The size of trace was also investigated to determine its influence on embryo viability during maturation. Early, mid and late-maturing varieties were investigated to determine if abortion occurs as the fruit matures similar to that found in early-ripening peaches (Blake, 1939).

\section{MATERIAL AND METHODS}

The genotypes studied were Thompson Seedless, Flame S., Perlette and Ruby S., the most important seedless grapes grown in California; Black Monukka and Autumn S., also cultivated in California; and the numbered genotypes which are selected clones from the USDA/ARS/HCRL breeding program. They were selected for this study for their seed trace size and ripening season, as shown in Table 1.

Three to four clusters of each genotype were randomly harvested at 6,10 and 14 weeks past bloom (wpb). At $18 \mathrm{wpb}$ fruit was harvested from the mid and late season selections only due to fruit availability. At $22 \mathrm{wpb}$ only fruit from late season genotypes were harvested.

Forty ovules (sced traces) were collected randomly from each genotype at each date and their weight and length were recorded. A third set of data was generated by dividing the weight by length to give an approximation of density.

Table 1. Seedless grape genotypes separated in groups according to ripening season and seed trace size

\begin{tabular}{|c|c|c|c|}
\hline \multirow{2}{*}{ Seed trace size } & \multicolumn{3}{|c|}{ Ripening season } \\
\hline & Early & Mid & Late \\
\hline \multirow[t]{2}{*}{ Small } & C67-7 & Thompson S. & Autumn $\mathrm{S}$. \\
\hline & C65-128 & C49-168 & Crimson $\mathrm{S}$. \\
\hline \multirow[t]{2}{*}{ Medium } & Flame S. & Black Monukka & Ruby Seedless \\
\hline & Perlette & P60-58 & C21-205 \\
\hline \multirow[t]{2}{*}{ Large } & B4-108 & C $35-33$ & B $40-208$ \\
\hline & C54-6 & B31-164 & C29-171 \\
\hline
\end{tabular}


Berries were surface sterilized through procedures previously reported (Emershad \& Ramming, 1984). From these, 40 ovules per genotype per date were cultured in $65 \mathrm{~mm}$ dia $\times 10 \mathrm{~mm}$ height orchid jars (Manufactured by P \& O.P. May, Queensland, Australia) on filter paper supports (\#541 Whatman, $90 \mathrm{~mm}$ diameter) with 10 ovules in each jar (4 replicates). The medium used was Cain's basal medium (Cain et al, 1983) plus 6\% sucrose (Emershad \& Ramming, 1984). After 8 weeks, embryos were excised, counted, measured for their length and evaluated for their stage that represents the various stages of embryo development of angiosperms in vivo. The scale used was: 1 = globular stage; 2 = heart stage; 3 = torpedo stage. Embryos that appeared to have somatic embryos developing from zygotic embryos were classified as multiples. They were counted and subcultured in $18 \times 150 \mathrm{~mm}$ test tubes with Woody Plant Medium (WPM) (Lloyd \& McCown, 1986) $+1.5 \%$ sucrose solidified with $0.7 \%$ TC agar. The normal appearing embryos were subcultured in orchid jars with liquid WPM $+1.5 \%$ sucrose on filter paper supports for 8 weeks. After this period the following traits were recorded: number of germinated embryos, plant weight and number of transplantable plants.

Data were analyzed by analysis of variance with means separated by Duncan's multiple range test GLM procedure of SAS software package.

\section{RESULTS AND DISCUSSION}

It was found that the number of ovules per berry is an intrinsic character of a genotype (Table 2) i.e., each genotype has a defined number of ovules per berry. Seed trace size did not influenced number of ovules/berry; for example, Thompson Seedless, with a very small seed trace showed 2.55 ovules per berry. On the other hand, B4-108 with a large seed trace, had only 1.37 ovules per berry. These findings can be used in future crosses between seedless genotypes since they will help to plan the number of emasculations necessary to reach a given number of ovules to be cultured.

Observing the effects of ripening season only (Table 3), differences were not significant for num- ber of multiples, embryo length and plant weight. Mid and late season genotypes possessed the longest and shortest seed traces respectively. The early genotypes had intermediate seed trace lengths, but they were the heaviest; the mid season genotypes possessed the lightest seed traces. Certain genotypes exhibited very long and shriveled seed traces, compared to others with shorter and heavier seed traces. This was the reason that permitted to calculate the weight/length index here termed density. Density, in this context seems to normalize the distribution of data, permitting better comparisons. Large density seed traces were found in the early season genotypes, being statistically different from mid and late season ones. Apparently collapsing of seed trace integuments starts later in the early season genotypes, but this was not histologically established.

Table 2. Average number of ovules found per berry of 18 seedless grape genotypes

\begin{tabular}{lc} 
Genotype & $\begin{array}{c}\text { Nr. ovules } \\
\text { per berry }\end{array}$ \\
\hline P60-58 & $3.00 \mathrm{a}$ \\
C54-6 & $2.73 \mathrm{ab}$ \\
C29-171 & $2.62 \mathrm{abc}$ \\
Ruby Seedless & $2.58 \mathrm{a}-\mathrm{d}$ \\
Thompson Seedless & $2.55 \mathrm{a}-\mathrm{e}$ \\
C35-33 & $2.48 \mathrm{a}-\mathrm{e}$ \\
Flame Seedless & $2.47 \mathrm{a}-\mathrm{e}$ \\
Autumn Seedless & $2.32 \mathrm{a}-\mathrm{f}$ \\
Crimson Seedless & $2.28 \mathrm{a}-\mathrm{f}$ \\
Perlette & $2.17 \mathrm{~b}-\mathrm{g}$ \\
C67-7 & $2.07 \mathrm{~b}-\mathrm{h}$ \\
B31-164 & $1.95 \mathrm{c}-\mathrm{h}$ \\
Black Monukka & $1.90 \mathrm{c}-\mathrm{h}$ \\
B40-208 & $1.88 \mathrm{~d}-\mathrm{h}$ \\
C49-168 & $1.84 \mathrm{c}-\mathrm{h}$ \\
C65-128 & $1.63 \mathrm{fgh}$ \\
C21-205 & $1.44 \mathrm{gh}$ \\
B4-108 & $1.37 \mathrm{~h}$ \\
\hline LSD (0.05) & 0.73
\end{tabular}


Table 3. Grape embryo culture characteristics as influenced by genotype ripening season

\begin{tabular}{lcccccccccc}
\hline Season & LTH( $\left.{ }^{1}\right)$ & WHT & DEN & EMB & MUL & ELT & EST & GEM & PWT & TRP \\
\hline & $\mathrm{mm}$ & $\mathrm{mg}$ & & & & $\mathrm{mm}$ & & & $\mathrm{g}$ & \\
& & & & & & & & & & \\
Early & $3.93 \mathrm{~b}$ & $10.33 \mathrm{a}$ & $2.45 \mathrm{a}$ & $2.33 \mathrm{a}$ & 0.30 & 0.92 & $2.42 \mathrm{~b}$ & $1.60 \mathrm{a}$ & 0.09 & $0.87 \mathrm{ab}$ \\
Mid & $4.50 \mathrm{a}$ & $8.78 \mathrm{c}$ & $1.78 \mathrm{~b}$ & $2.33 \mathrm{a}$ & 0.45 & 0.92 & $2.62 \mathrm{a}$ & $1.75 \mathrm{a}$ & 0.12 & $1.14 \mathrm{a}$ \\
Late & $3.65 \mathrm{c}$ & $9.31 \mathrm{~b}$ & $1.80 \mathrm{~b}$ & $1.23 \mathrm{~b}$ & 0.20 & 1.08 & $2.54 \mathrm{ab}$ & $0.85 \mathrm{~b}$ & 0.11 & $0.49 \mathrm{~b}$ \\
\hline
\end{tabular}

( ${ }^{1}$ LTH = Seed trace length; WHT = Seed trace weight; DEN = Seed trace density; EMB = Number of embryos rescued; MUL $=$ Number of multiple embryos found; ELT = Embryo length; EST = Embryo stage; GEM = Number of germinated embryos; PWT $=$ Plant weight; TRP $=$ Number of transplantable plants.

Table 4. Grape embryo culture characteristics as influenced by culture date (weeks post bloom) for all genotypes

\begin{tabular}{lcccccc}
\hline Culture date & LTH $\left({ }^{1}\right)$ & WHT & DEN & EMB & MUL & ELT \\
\hline & $\mathrm{mm}$ & $\mathrm{mg}$ & & & & $\mathrm{mm}$ \\
6 & $3.74 \mathrm{~d}$ & $10.28 \mathrm{a}$ & $2.28 \mathrm{a}$ & $2.70 \mathrm{a}$ & $0.72 \mathrm{a}$ & $0.88 \mathrm{c}$ \\
10 & $3.89 \mathrm{c}$ & $8.65 \mathrm{c}$ & $1.92 \mathrm{~b}$ & $2.64 \mathrm{a}$ & $0.44 \mathrm{~b}$ & $0.92 \mathrm{bc}$ \\
14 & $4.20 \mathrm{~b}$ & $9.30 \mathrm{bc}$ & $1.92 \mathrm{~b}$ & $1.17 \mathrm{~b}$ & $0.09 \mathrm{c}$ & $0.93 \mathrm{bc}$ \\
18 & $4.58 \mathrm{a}$ & $9.62 \mathrm{~b}$ & $1.74 \mathrm{c}$ & $1.21 \mathrm{~b}$ & $0 \mathrm{c}$ & $1.31 \mathrm{~b}$ \\
22 & $3.39 \mathrm{e}$ & $8.62 \mathrm{c}$ & $1.62 \mathrm{~d}$ & $0.46 \mathrm{c}$ & $0 \mathrm{c}$ & $1.70 \mathrm{a}$ \\
\hline
\end{tabular}

Interaction

cult.date*genotype

\begin{tabular}{|c|c|c|c|c|c|}
\hline Culture date & EST & GEM & PWT & TRP & TRP/EMB \\
\hline & & & $\mathrm{g}$ & & $\%$ \\
\hline 6 & $2.26 \mathrm{~b}$ & $1.97 \mathrm{a}$ & 0.10 & $1.27 \mathrm{a}$ & 47.04 \\
\hline 10 & $2.71 \mathrm{a}$ & $2.04 \mathrm{a}$ & 0.11 & $1.24 \mathrm{a}$ & 47.00 \\
\hline 14 & $2.67 \mathrm{a}$ & $0.78 \mathrm{~b}$ & 0.12 & $0.36 \mathrm{~b}$ & 30.77 \\
\hline 18 & $2.63 \mathrm{a}$ & $0.70 \mathrm{bc}$ & 0.09 & $0.43 b$ & 35.54 \\
\hline 22 & $2.80 \mathrm{a}$ & $0.32 \mathrm{c}$ & 0.16 & $0.14 b$ & 30.43 \\
\hline \multicolumn{6}{|l|}{ Interaction } \\
\hline cult.date*genotype & $* *$ & $* *$ & ns & $* *$ & \\
\hline
\end{tabular}

(') See footnote in Table 3 for legend. 
The number of rescued embryos was the same for early and mid season genotypes, which was approximately double the value found in late season types. It appears from this data that if late season genotypes are used in seedless $\mathrm{X}$ seedless crosses, it may be difficult in rescuing an adequate number of embryos.

A more advanced stage of embryo development was found in mid season genotypes than in the early ones. The stage of embryo development in the late season types was intermediate to the others. The early and mid season genotypes had almost twice as many germinated embryos when compared to the late season types. The greatest number of transplantable plants was established from mid season types followed by the early ones although not statistically greater than late ones.

Table 4 shows the pooled effect of culture dates. Length of seed trace increased from 6 to $18 \mathrm{wpb}$, but severely decreased in the fifth date. It must be mentioned that only the late genotypes were evaluated in the last date and it was noted that these genotypes showed the shortest seed trace. Seed trace weight was influenced by culture date in a non linear pattern probably due to genotype vs. culture date interactions. Seed trace density statistically decreased with later culture dates probably accompanying a progressive collapse in the endosperm and shriveling of integuments. It must be remembered that only the late season types reached all culture dates.

The number of embryos decreased with culture date. The greatest number of embryo was found at 6 and $10 \mathrm{wpb}$. Germination was two times better than for embryes at 14 and $18 \mathrm{wpb}$ and all were better than $22 \mathrm{wpb}$. From this, one can suggest that it is the most efficient to culture traces 6-10 wpb to obtain the greatest number of embryos and plants.

Somatic embryos are frequently produced from zygotic embryos isolated from grape berries (Stamp \& Meredith, 1988; Emershad et al., 1989). Multiple embryos found in previous works were budding adventitiously from the hypocotyl-root axis of zygotic embryos or as clusters of embryos at various stages of development located at the micropylar end of the ovule (Emershad et al., 1989). Multiple embryos could also develop from mother tissue.

In the present work, the number of multiple embryos decreased with culture date. At $6 \mathrm{wpb}$, it was the highest and the number dropped to zero in the last two dates. Maybe the manipulation of embryos at early harvest dates or their immature stage at that time could influence the formation of multiple embryos. In this case, these findings could be a relevant contribution to research dealing with regeneration efficiency or manipulation. On the other hand, for breeding purposes, where only one embryo per crossing is wanted, the later dates are the best.

Embryo length and stage increased with culture date. Embryos of the last date were twice as long as those of the first date. It seems like the embryos keep growing in length, while still in the berries attached to the plants.

The number of germinated embryos decreased with culture date and, again, the first two dates showed the highest number, following almost the same pattern reported for total number of embryos. This fact also reflects the highest number of transplantable plants for the first two culture dates.

It seems that the most important trait is the total number of rescued embryos because the other traits like number of germinated embryos and number of transplantable plants follow the same tendency. One can say that more embryos rescued, more plants will be recovered.

Table 5 shows that genotypes are a major source of variation for the traits studied and all were influenced. Statistically different genotypes were found for all characteristics and they can be seen even amongst the same group of ripening season. The tendency already discussed can be seen here: genotypes with the densest ovules had more embryos, which germinated more and developed more transplantable plants.

There were exceptions like $\mathrm{P} 60-58$ with average size seed traces, but with a great number of embryos, the largest number of germinated embryos 
and the largest number of plants. This confirms the findings of Emershad et al. (1989) who found P60-58 with the greatest number of enlarged embryos compared to Thompson Seedless. On the other hand, B40-208 with a large and dense seed trace, contained very few embryos and consequently a small number of germinated embryos and transplantable plants.

This also confirms unpublished data (Emershad, R., personal communication) that showed the recovery of a very small number of embryos from B40-208 which had been extensively used as a female parent in crosses made in 1988.

This fact was so significant that B40-208 is now used as a male parent in the breeding program. The general tendency of the densest ovules to present more embryos has a great value in giving direction in determining the optimum culture date, trace size and season of maturity for optimum embryo rescue results. However, investigations must be done to determine why exceptions like P60-58 and $\mathrm{B} 40-208$ exist.

When genotypes are grouped by their seed trace densities, as a measure of their size without the exceptional cases of P60-58 and B40-208, the following values were found:

$\begin{array}{lccccc}\text { Size } & \text { DEN } & \text { EMB } & \text { ELT } & \text { GEM } & \text { TRP } \\ \text { Large } & 3.54 & 3.10 & 1.00 & 2.37 & 1.50 \\ \text { Medium } & 2.24 & 2.54 & 1.03 & 1.63 & 0.64 \\ \text { Med.-small } & 1.29 & 1.51 & 0.87 & 1.00 & 0.52 \\ \text { Small } & 0.73 & 0.73 & 0.67 & 0.34 & 0.16\end{array}$

The correlation between seed trace density and the other traits show that the bigger the seed trace, the larger the number of ovules with embryos ( $r$ $\left.=0.97^{*}\right)$, the larger the number of germinated embryos $\left(r=0.99^{*}\right)$, and the larger the number of transplantable plants $(r=0.97 *)$.

The correlation between seed trace density and embryo length is also significant, but it is not as evident $\left(0.82^{*}\right)$. In other words, the success of embryo culture depends to a high degree on seed trace size. This observation can be of great value for breeding programs, especially when no specific data on certain genotypes are available.

Figure 1 shows data resulting from analysis of variance for culture date by season. Although the comparisons can be made only within the season, it is apparent that for seed trace length and weight, embryo stage and plant weight the figures are somewhat homogenous through season and culture date. Data for number of embryos, germinated embryos, multiples, and transplantable plants showed decreasing values for the last dates. Embryo length, on the contrary, showed largest values in the last dates.

Figure 2 shows data from analysis of variance for genotype by season. Again, the comparisons must be made only within the season, but embryo length and stage showed the least amount of variability. For all other traits the influence of genotypes is evident, despite the effect of season.

Tables 6,7 and 8 were constructed with data only from the first three culture dates $(6,10$ and $14 \mathrm{wpb}$ ) in order to verify the trends already seen and to determine if the last two dates influenced the results. As can be seen, only small changes were found. The results obtained from all 5 dates is very similar to that obtained only from the first 3 culture dates.

Even the correlations mentioned before were still valid (Fig. 3) when using only the first 3 culture dates. The regression lines on the left were obtained with all the 18 genotypes in the first three dates; those on the right were obtained without P60-58 and $\mathrm{B} 40-208$.

Correlation coefficient between seed trace density and number of embryo changed from 0.65 to 0.83 ; among density and number of transplantable plants, from 0.60 to 0.89 . It did not change significantly between density and embryo length $(0.63$ to 0.65 ). This means that a breeder can evaluate the potential of a genotype to be successful in embryo culture based on the density of its seed trace. 


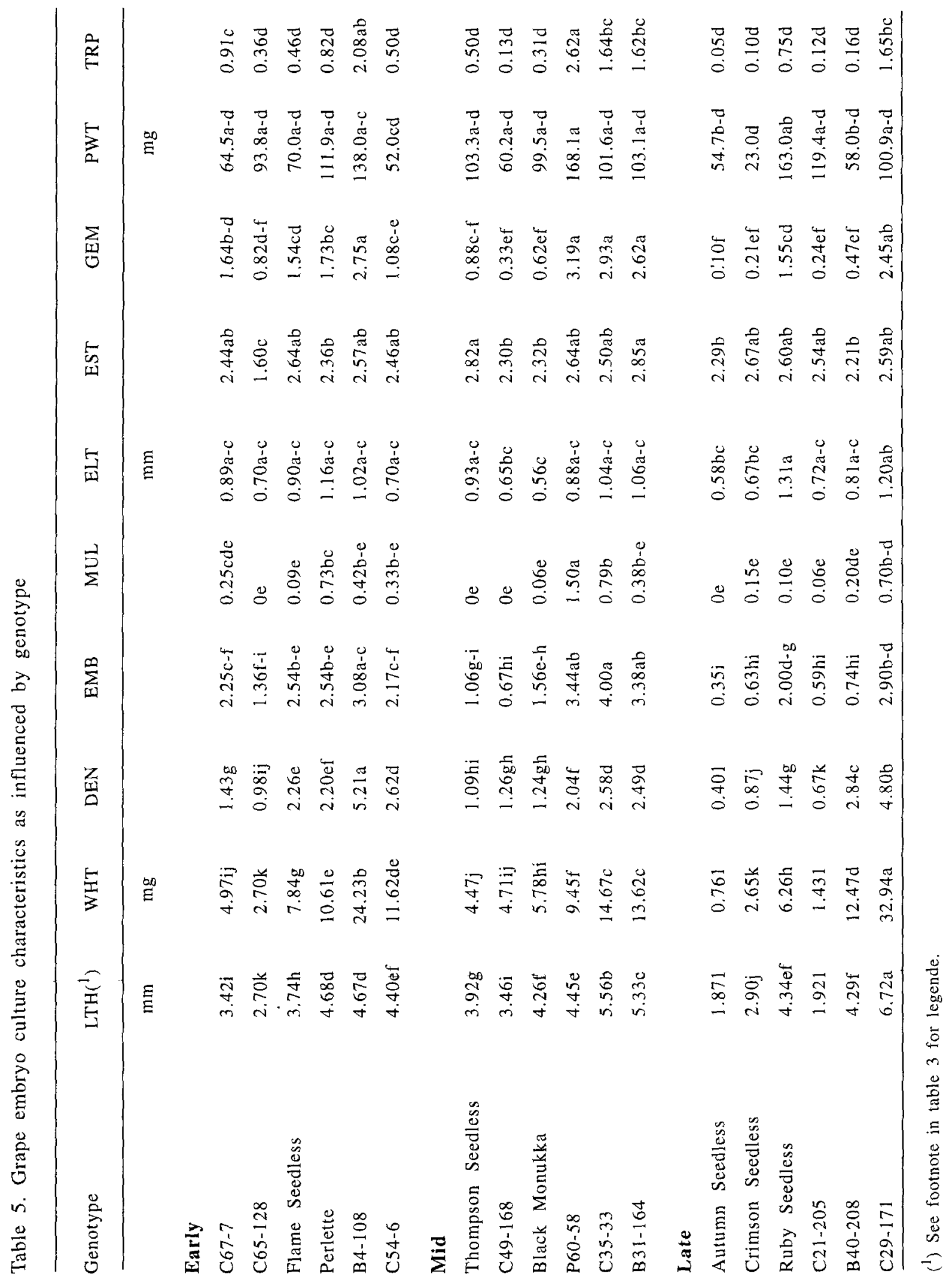



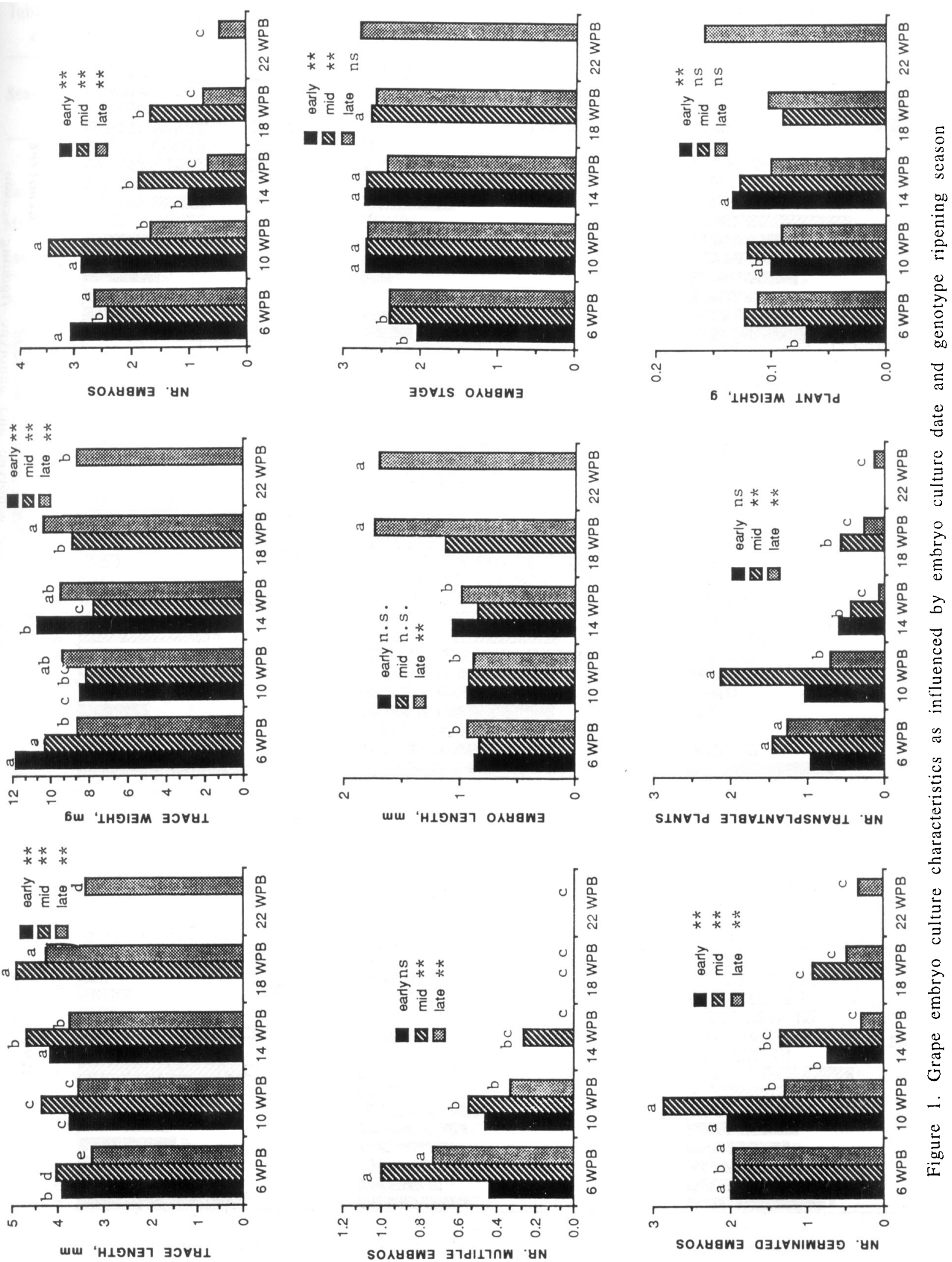


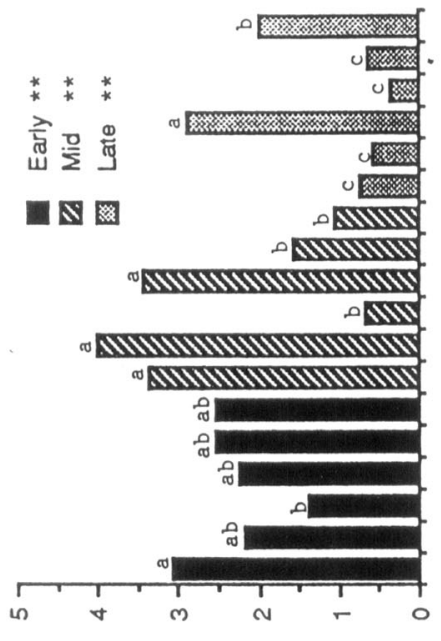

Sоку8พэ 'yN

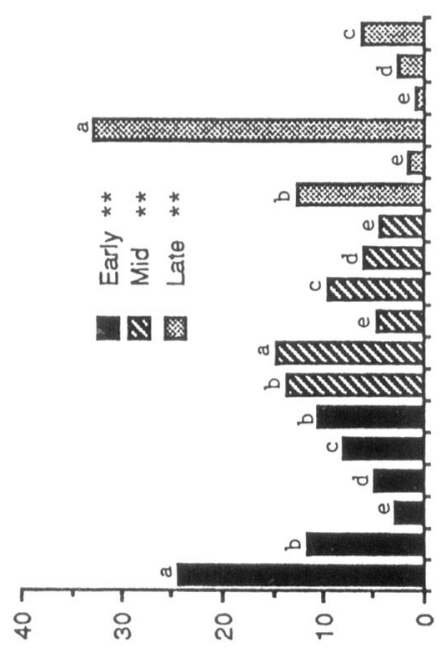

6 “ ‘

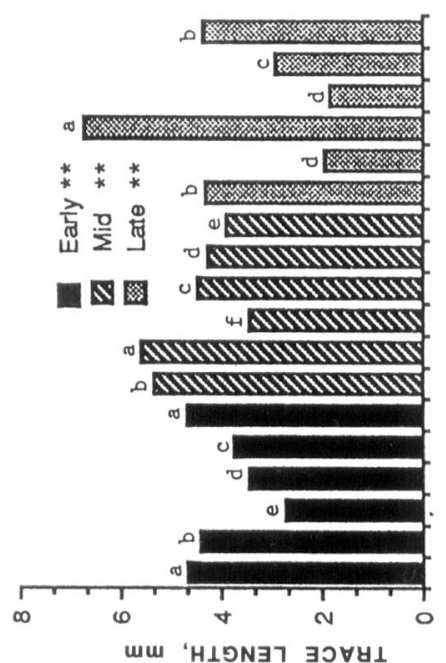

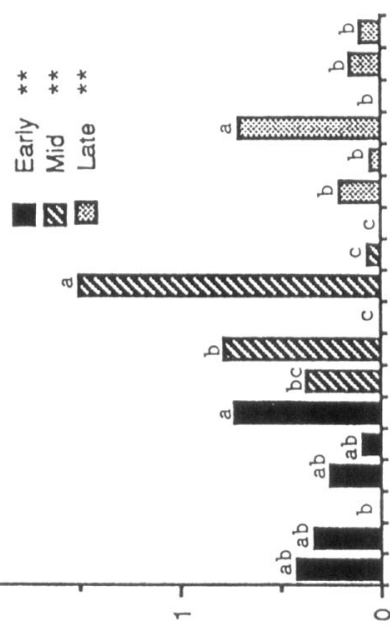

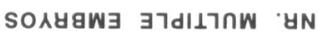

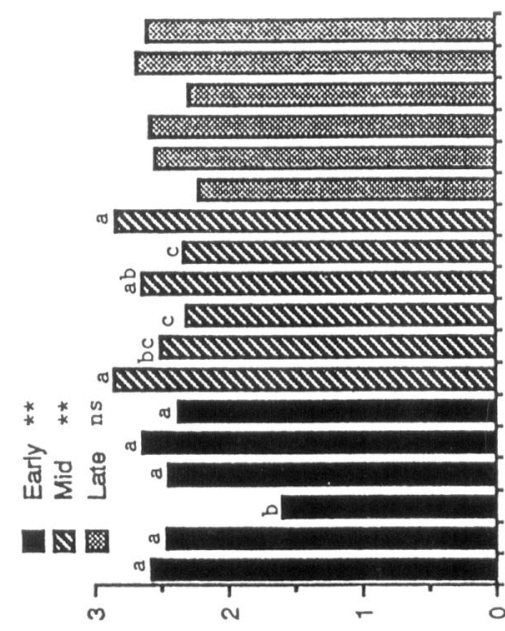

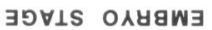

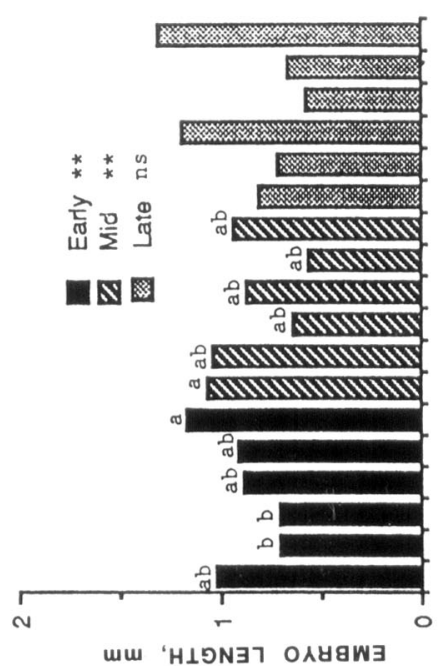

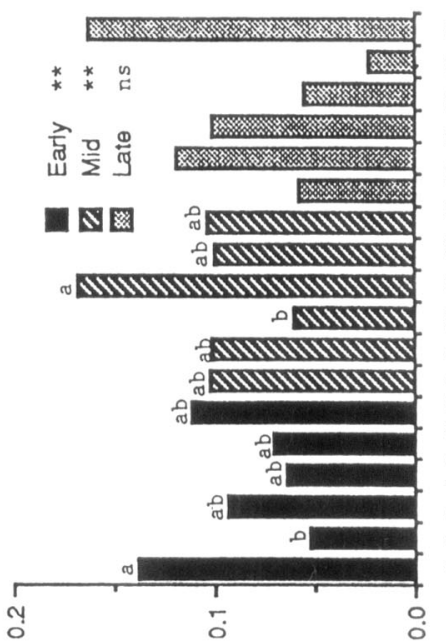

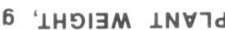

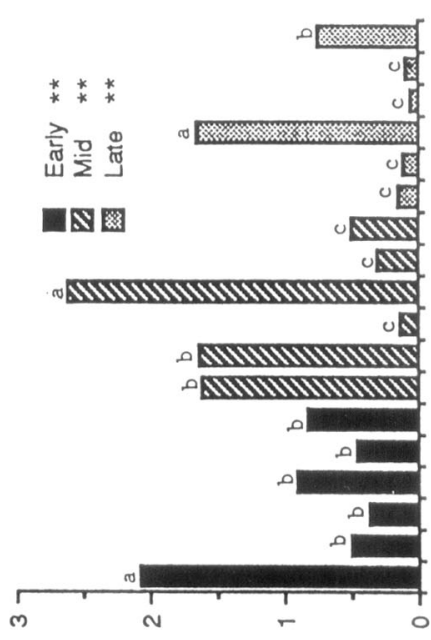

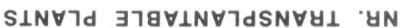
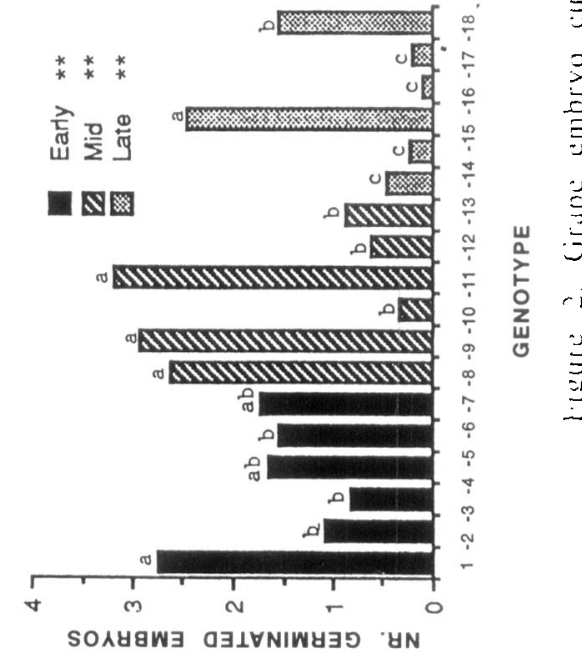
Table 6. Grape embryo culture characteristics as influenced by season for only the first three embryo culture dates

\begin{tabular}{|c|c|c|c|c|}
\hline \multirow{2}{*}{ Season } & \multirow{2}{*}{$\begin{array}{c}\text { Number of } \\
\text { embryos }\end{array}$} & \multicolumn{2}{|c|}{ Embryo } & \multirow{2}{*}{$\begin{array}{l}\text { Number of trans } \\
\text { plantable plants }\end{array}$} \\
\hline & & Length & Stage $\left({ }^{1}\right)$ & \\
\hline & & $\mathrm{mm}$ & & \\
\hline Early & $2.33 \mathrm{a}$ & 0.92 & $2.42 \mathrm{~b}$ & $0.87 b$ \\
\hline Mid & $2.56 a$ & 0.87 & $2.61 \mathrm{a}$ & $1.33 \mathrm{a}$ \\
\hline Late & $1.63 \mathrm{a}$ & 0.92 & $2.51 \mathrm{ab}$ & $0.67 b$ \\
\hline
\end{tabular}

(l) 1 = globular stage: $2=$ heart stage: 3 = torpedo stage.

$\sum_{\substack{c \\ 0}}^{\frac{c}{u}}$
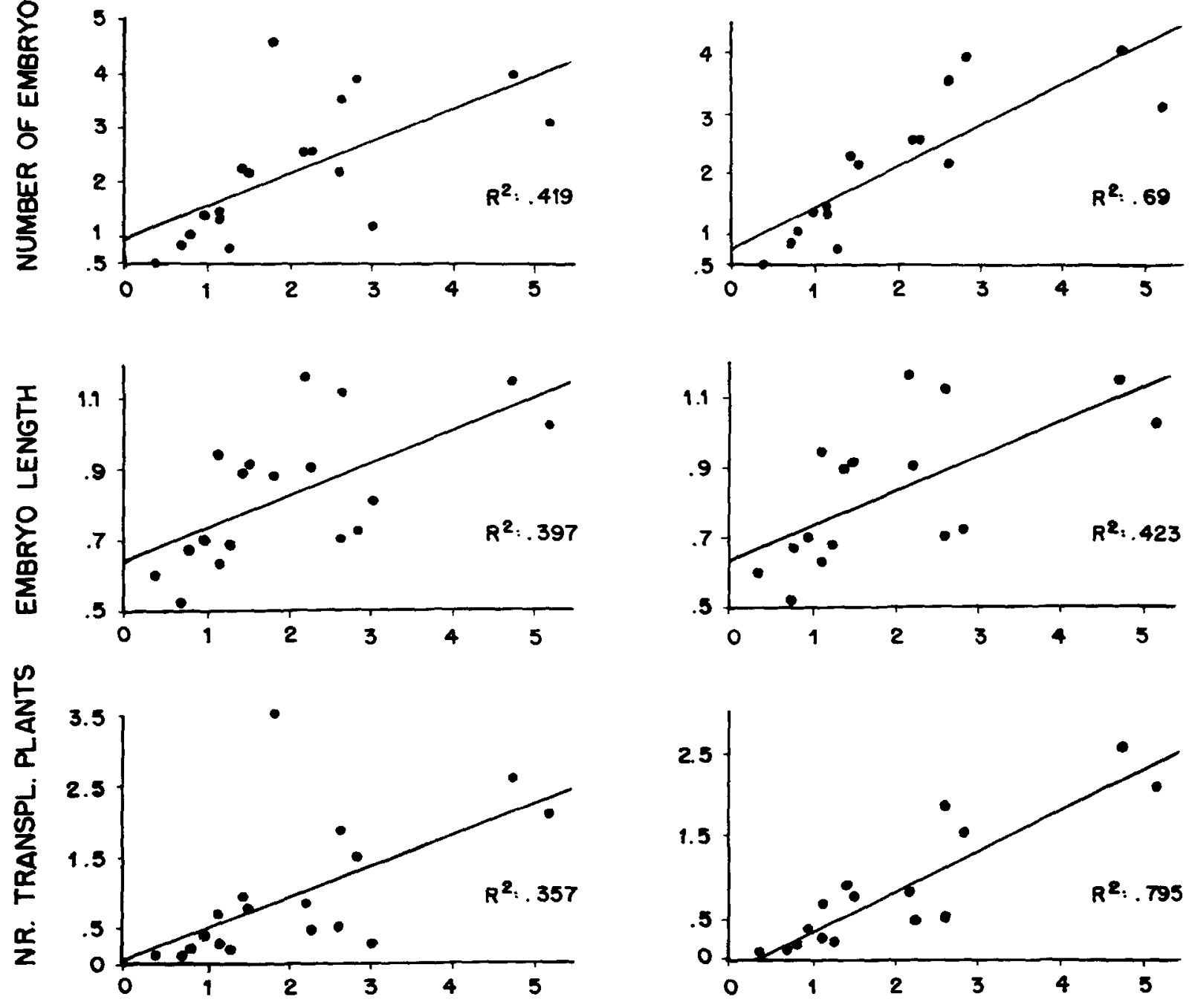

\section{DENSITY}

Figure 3. Correlation among number of embryos, embryo length and number of transplantable plants respectively with seed trace density of eighteen seedless grape genotypes. On the right, lines obtained without data from genotypes P60-58 and B40-208. 
Table 7. Grape embryo culture characteristics as influenced by culture date for only the first three embryo culture dates

\begin{tabular}{ccccc}
\hline Culture date & $\begin{array}{c}\text { Number of } \\
\text { embryos }\end{array}$ & Length & Embryo & $\begin{array}{c}\text { Number of trans- } \\
\text { plantable plants }\end{array}$ \\
\cline { 3 - 4 } & & $\mathrm{mm}$ & & \\
6 & $2.70 \mathrm{a}$ & 0.88 & $2.26 \mathrm{~b}$ & $1.24 \mathrm{a}$ \\
10 & $2.64 \mathrm{a}$ & 0.92 & $2.71 \mathrm{a}$ & $1.27 \mathrm{a}$ \\
14 & $1.17 \mathrm{~b}$ & 0.93 & $2.67 \mathrm{a}$ & $0.36 \mathrm{~b}$ \\
\hline
\end{tabular}

Interaction

cult.date*genotype

** $* *$

$* *$

(1) $1=$ globular stage; $2=$ heart stage; $3=$ torped stage.

Table 8. Grape embryo culture characteristics as influenced by genotype for only the first three embryo culture dates

\begin{tabular}{|c|c|c|c|c|c|}
\hline \multirow{2}{*}{ Genotype } & \multirow{2}{*}{$\begin{array}{l}\text { Number of } \\
\text { embryos }\end{array}$} & \multicolumn{2}{|c|}{ Embryo } & \multirow{2}{*}{$\begin{array}{l}\text { Number of trans- } \\
\text { plantable plants }\end{array}$} & \multirow{2}{*}{$\begin{array}{l}\text { Plants per } \\
\text { embryo }\end{array}$} \\
\hline & & Length & Stage $\left({ }^{1}\right)$ & & \\
\hline
\end{tabular}

\section{Early}

\begin{tabular}{llllll} 
C67-7 & $2.25 \mathrm{~d}-\mathrm{f}$ & $0.89 \mathrm{a}-\mathrm{c}$ & $2.44 \mathrm{a}-\mathrm{d}$ & $0.91 \mathrm{~d}-\mathrm{f}$ & 40.4 \\
C65-128 & $1.36 \mathrm{e}-\mathrm{g}$ & $0.70 \mathrm{a}-\mathrm{c}$ & $1.60 \mathrm{e}$ & $0.36 \mathrm{f}$ & 26.5 \\
Flame Seedless & $2.54 \mathrm{c}-\mathrm{e}$ & $0.90 \mathrm{a}-\mathrm{c}$ & $2.64 \mathrm{a}-\mathrm{d}$ & $0.46 \mathrm{ef}$ & 18.1 \\
Perlette & $2.54 \mathrm{c}-\mathrm{e}$ & $1.16 \mathrm{a}$ & $2.36 \mathrm{~b}-\mathrm{d}$ & $0.82 \mathrm{~d}-\mathrm{f}$ & 32.3 \\
B4-108 & $3.08 \mathrm{~b}-\mathrm{d}$ & $1.02 \mathrm{ab}$ & $2.57 \mathrm{a}-\mathrm{d}$ & $2.08 \mathrm{bc}$ & 67.5 \\
C54-6 & $2.17 \mathrm{~d}-\mathrm{f}$ & $0.70 \mathrm{a}-\mathrm{c}$ & $2.46 \mathrm{a}-\mathrm{d}$ & $0.50 \mathrm{ef}$ & 23.0 \\
Mid & & & & \\
Thompson Seedless & $1.33 \mathrm{e}-\mathrm{g}$ & $0.94 \mathrm{a}-\mathrm{c}$ & $2.81 \mathrm{ab}$ & $0.67 \mathrm{ef}$ & 50.4 \\
C-49-168 & $0.73 \mathrm{~g}$ & $0.68 \mathrm{a}-\mathrm{c}$ & $2.25 \mathrm{~cd}$ & $0.18 \mathrm{f}$ & 24.7 \\
Black Monukka & $1.42 \mathrm{e}-\mathrm{g}$ & $0.63 \mathrm{bc}$ & $2.41 \mathrm{a}-\mathrm{d}$ & $0.25 \mathrm{f}$ & 17.6 \\
P60-58 & $4.58 \mathrm{a}$ & $0.88 \mathrm{a}-\mathrm{c}$ & $2.64 \mathrm{a}-\mathrm{d}$ & $3.50 \mathrm{a}$ & 76.4 \\
C35-33 & $3.90 \mathrm{ab}$ & $0.72 \mathrm{a}-\mathrm{c}$ & $2.38 \mathrm{a}-\mathrm{d}$ & $1.50 \mathrm{c}-\mathrm{e}$ & 38.5 \\
B31-164 & $3.50 \mathrm{a}-\mathrm{c}$ & $1.12 \mathrm{a}$ & $2.86 \mathrm{a}$ & $1.83 \mathrm{~b}-\mathrm{d}$ & 52.3 \\
Late & & & & 16.0 \\
Autumn Seedless & $0.50 \mathrm{~g}$ & $0.60 \mathrm{bc}$ & $2.17 \mathrm{~d}$ & $0.08 \mathrm{f}$ & 17.0 \\
Crimson Seedless & $1.00 \mathrm{fg}$ & $0.67 \mathrm{a}-\mathrm{c}$ & $2.67 \mathrm{a}-\mathrm{c}$ & $0.17 \mathrm{f}$ & 34.6 \\
Ruby Seedless & $2.17 \mathrm{~d}-\mathrm{f}$ & $0.91 \mathrm{a}-\mathrm{c}$ & $2.46 \mathrm{a}-\mathrm{d}$ & $0.75 \mathrm{ef}$ & 12.5 \\
C21-205 & $0.80 \mathrm{~g}$ & $0.52 \mathrm{c}$ & $2.67 \mathrm{a}-\mathrm{c}$ & $0.10 \mathrm{f}$ & 21.4 \\
B40-208 & $1.17 \mathrm{fg}$ & $0.81 \mathrm{a}-\mathrm{c}$ & $2.21 \mathrm{~cd}$ & $0.25 \mathrm{f}$ & 64.5 \\
C29-171 & $4.00 \mathrm{ab}$ & $1.15 \mathrm{a}$ & $2.60 \mathrm{a}-\mathrm{d}$ & $2.58 \mathrm{ab}$ & \\
\hline
\end{tabular}

(1) 1 = globular stage; 2 = heart stage; $3=$ torped stage. 


\section{CONCLUSIONS}

1. Genotype influenced embryo culture traits according to their own potential.

2. Late maturing genotypes showed fewer rescued embryos, germinated embryos and transplantable plants than early and mid season ones.

3. The best culture time for grape embryo rescue is 6 and 10 weeks past bloom. The largest number of embryos, germinated embryos and transplantable plants were obtained at these dates.

4. Genotypes with largest ratio for seed trace weight/seed trace length (i.e., largest density) showed the greatest tendency to have the largest number of ovules with embryos, more germinated embryos and more transplantable plants.

5. The study also showed that it is possible to recover plants from mature fruits harvested late, although at a much reduced rate.

\section{ACKNOWLEDGMENT}

The authors thank Mr. Max Harris, Horticultural Crops Research Laboratory, USDA/ARS, Fresno, $\mathrm{CA}$ for running the statistical analysis.

\section{LITERATURE CITED}

BARLASS, M.; RAMMING, D.W. \& DAVIS, H.P. Inovulo embryo culture: a breeding technique to rescue seedless x seedless table grapes. The Australian Grapegrower \& Winemaker. 1988, p.123-125.

BLAKE, M.A. Some results of crosses of early ripening varieties of peaches. Proceedings of the American Society Horticultural Science, Alexandria, 37:232$241,1939$.

BOUQUET, A. \& DAVIS, H.P. Culture in vitro d'ovules et d'embryons de vigne (Vitis vinifera L.) appliquée a la selection de varietés de raisins de table sans pepins. Agronomie, Paris, 9:565, 574, 1989.
CAIN, D.W.; EMERSHAD, R.L. \& TARAILO, R.E. Inovulo embryo culture and seedling development of seeded and seedless grapes (Vitis vinifera L.). Vitis, Siebeldingen, 22:9-14, 1983.

EMERSHAD, R.L. \& RAMMING, D.W. In-ovulo embryo culture of Vitis vinifera L. cv. Thompson Seedless. HortScience, Alexandria, 17:576, Abstr. 1982.

EMERSHAD, R.L. \& RAMMING, D.W. In-ovulo embryo culture of Vitis vinifera L. cv. 'Thompson Seedless'. American Journal of Botany, Columbus, 71:873-877, 1984.

EMERSHAD, R.L.; RAMMING, D.W. \& SERPE, M.S. In-ovulo embryo development and plant formation from stenospermic genotypes of Vitis vinifera. American Journal of Botany, Columbus, 76(3):397-402, 1989.

GOLDY, R.G. \& AMBORN, U. In vitro culturability of ovules from 10 seedless grape clones. HortScience, Alexandria, 22:952, 1987.

GRAY, D.J.; MORTENSEN, J.A.; BENTON, C.M.; DURHAM, R.E. \& MOORE, G.A. Ovule culture to obtain progeny from hybrid seedless bunch grapes. Journal of the American Society Horticultural Science, Alexandria, 115:1019-1024, 1990.

LLOYD, G. \& McCOWN, B. Commercially-feasible micropropagation of mountain laurel. Kalmia latifolia, by use of shoot tip culture. Proceedings of International Plant Propagation Society, 30:421-427, 1986.

PEARSON, H.M. Parthenocarpy and seedlessness in Vitis vinifera. Science, Washington, DC., 76:594, 1932.

RAMMING, D.W. The use of embryo culture in fruit breeding. HortScience, Alexandria, 25(4):393-398, 1990.

SPIEGEL-ROY, P.; SAHAR, N.; BARON, J. \& LAVI, U. In vitro culture and plant formation from grape cultivars with abortive ovules and seeds. Journal of the American Society Horticultural Science, Alexandria, 110(1):109-112. 1985.

STAMP, J.A. \& MEREDITH, C.P. Proliferative somatic embryogenesis from zygotic embryos of grapevine, Journal of the American Society Horticultural Science, Alexandria, 113(6):941-945, 1988.

STOUT, A.B. Seedlessness in grapes. New York Agricultural Experiment Station 1936, (Techn. Bull., 238) 